\section{A Short History of the Microsurgery Training and Research Laboratory at Gulhane Military Medical Academy}

\author{
Gülhane Askeri Tıp Akademisinde \\ Mikrocerrahi Eğitim ve Araștırma \\ Laboratuvarı'nın Kısa Tarihi
}

\begin{abstract}
Microsurgical techniques have played a crucial role in the development of neurosurgery and microsurgical education has an involuting role to gain surgical competence in neurosurgery. Microsurgery laboratory at Gulhane Military Medical Academy (GMMA) was established in 1985 by Prof. Erdener Timurkaynak within the Research-Development Building. From the beginning, education of the surgeons in microsurgery has been regarded as the essential function of this center, but many experimental and anatomical researches have also taken place in this laboratory. Over the past twenty-five years, 288 courses had been held in the microsurgical laboratory and more than 1000 surgeons from different fields and specialties were trained. Many of them conducted hundreds of research projects and published scientific papers during this period.

This laboratory enters in the 21st century as a dynamic research and education center committed to the continuing delivery of education, as well as ongoing research of microsurgery for the coming 100 years.
\end{abstract}

KEYWORDS: Microsurgery, Laboratory, History, Neurosurgery

ÖZ

Mikrocerrahi teknikler nöroşirürjinin gelişiminde önemli rol oynamıştır ve mikrocerrahi eğitiminin cerrahi yetenek kazanmada vazgeçilmez bir önemi vardır. Gülhane Askeri Tıp Akademisinde (GATA) mikrocerrahi laboratuvarı 1985 yılında Dr. Erdener Timurkaynak tarafından Araştırma ve Geliştirme binası içinde kurulmuştur. Başlangıcından itibaren cerrahların mikrocerrahi eğitimi bu merkezin temel fonksiyonu olmuş, ancak pek çok anatomik ve deneysel araştırma da bu laboratuvarda yapılmıştır. Geçen 25 yılda, mikrocerrahi laboratuvarında 288 kurs düzenlenmiş ve farklı branş ve alanlardan 1000'in üzerinde cerrah eğitim almıştır. Bu süre içinde yüzlerce araştırma projesi gerçekleştirilmiş ve bilimsel makaleler yayınlanmıştır. Bu laboratuvar 21. yüzyıla dinamik bir eğitim ve araştırma merkezi olarak girmiş ve gelecek 100 yıl içinde mikrocerrahi eğitimi vermeye ve araştırmalara devam edecektir.

ANAHTAR SÖZCÜKLER: Mikrocerrahi, Laboratuvar, Tarihçe, Nöroşirürji

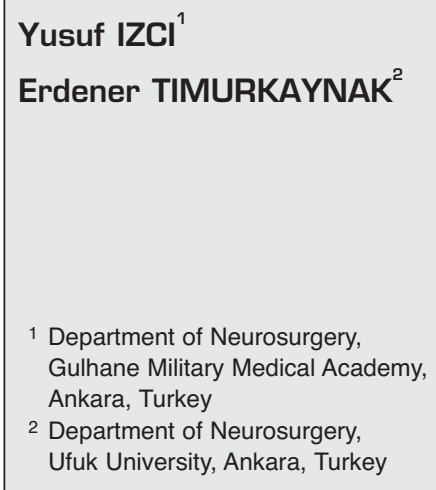

Received : 18.01.2010

Accepted : 15.02.2010

Correspondence address:

Yusuf IZCI

Beyin ve Sinir Cerrahisi Anabilim Dalı

Gülhane Askeri Tıp Akademisi

06018 Etlik-Ankara, Turkey

Phone : +90 3123045318

Fax : :90 3123045300

E-mail : yusufizci@yahoo.com 


\section{INTRODUCTION}

The major responsibility of an academic hospital is postgraduate education and research. The changes that occurred during the late 1970's have created the need for surgeons to re-train themselves several times. In early 1980's, the Academy embraced microsurgical techniques and decided to establish a microsurgery training and research laboratory to learn these techniques within the ResearchDevelopment Building. Microscopes and equipments for five workstations were purchased and thus formed the base of laboratory. After many efforts, the laboratory was opened and the first course took place in November 18, 1985. Over the years, the numbers of surgeons attending these courses, four or five at a time, has grown to over 1000. In addition, many research projects have been conducted in this laboratory by scientists from other clinics, hospitals and universities.

\section{History of Microsurgery in the world:}

The term "microsurgery" was first used as early as 1892, but then it referred to the study of neurological pathways in amphibia. Microsurgery was developed in the twentieth century by combining the techniques of vascular surgery with an operating microscope, fine instruments, microsuture and new operative strategy and techniques. (1). It was developed as a culmination of achievement in vascular surgery. The first vascular anastomosis was performed by J.B. Murphy in 1897, but Alexis Carrel originated the method for triangulation of blood vessels to perform arterial and venous repairs in 1902. He performed an end-to-end anastomosis. In 1908, he had devised methods for the transplantation of whole organs. Together with C.C. Guthrie, Carrel was able to amputate and reattach an entire lower limb at the level of the thigh in an animal. Carrel was born in France but worked at the Rockefeller Institute in New York City and was awarded the Nobel Prize in Medicine and Physiology in 1912, "in recognition of his work on vascular suture and the transplantation of bloodvessels and organs".(1)

The Second World War provided momentum for further advancement in vascular surgery. With the introduction of antibiotics in clinical surgery and the prevention of infection, the results improved and vascular surgeons developed more sophisticated sutures and instrumentation. Small vessels on the order of two to three millimeters were still beyond the scope of routine practice.

It was in 1960 that Jules Jacobson, a vascular surgeon, described microsurgical anastomoses in vessels as small as 1.4 millimeters using a microscope. Working at the University of Vermont, Jacobson found that a microscope used by ear, nose and throat surgeons for surgery on the middle ear could help in small vessel repair. Not surprisingly, he was the first to use the term "microvascular surgery". In 1961, Dr. Jacobson published the tremendously influential paper "Microsurgery in anastomosis of small arteries" in Surgical Forum with Dr. Suarez. They suggested the use of a surgical microscope to the neurosurgeons. Once started being used, it became indispensable and the counterpiece of instrument development at that institution thereafter. (1)

In 1962, a traumatic arm amputation was reattached surgically for the first time when Malt and McKhann described their experience with a tenyear-old boy. Microsurgical techniques were not used since the amputation was at the level of the upper arm where blood vessels were large enough to repair by the conventional methods.

In 1963 Goldwyn, Laub and White attempted to use macrovascular techniques to transplant large island flaps in animals. They were unsuccessful without fine suture and microsurgery but Kleinert and Kasdan reported the successful revascularization of a incompletely amputated thumb in 1963. (1)

Raymond M. P. Donaghy was one of the true pioneers of modern neurosurgery. His tireless dedication, innovation, and desire to humbly disseminate his knowledge facilitated the advancement of the field of microneurosurgery. He and Dr. Jacobson performed the first microsurgery in their laboratories using a Zeiss OPMI-1 microscope (single-head stereomicroscope) that was borrowed from the otolaryngology department. Many of today's most gifted neurosurgeons learned the art of microneurosurgery in Dr. Donaghy's laboratory. (2)

Prof. Gazi Yaşargil is one of the pioneers of microneurosurgery and he performed an anastomosis between the superficial temporal artery and a branch of the middle cerebral artery on a dog 
at the Microsurgical Laboratory at the University of Vermont in 1965. He performed the first extracranial-intracranial procedure on a human being, on October 30, 1967. (1) The advent of microneurosurgery necessitated a review of instrumentation. First, of course, the microscope itself required adaptation to the requirements of neurosurgery. Improved illumination and versatility in maneuverability is crucial so that the microscope could be set up for surgery in several positions. More sophisticated microscopes have now been developed, such as the one that's used by Yaşargil, which has a free moving head that is so neatly balanced as to follow the pressure of the lips.

Professor Albert L. Rhoton Jr. is one of the leaders of microneurosurgical anatomy researches in USA. In the early 1970's, he founded the Theodore Gildred Microneurosurgical Education and Research Center in the University of Florida and directed until today. He educated many neurosurgeons from all over the world. He made significant contributions in neuroanatomy and published many papers on the microsurgical anatomy of human brain.

\section{The Microsurgical Laboratory in GMMA:}

Dr. Erdener Timurkaynak took his microsurgical education in the Department of Neurosurgery, University of Florida between December 1980 and December 1981, under the supervision of Prof. Albert L. Rhoton. He performed excessive neuroanatomical studies especially on the microsurgical anatomy of the ventricles in the Theodore Gildred Microsurgical Education Center. After his return to Turkey, he began practicing microsurgery in the Department of Neurosurgery at GMMA, and tried to establish a microsurgical laboratory to provide formal instruction in the skills needed for microsurgical dissections, microvascular anastomoses and neurorrhaphies.(3) After many efforts, the laboratory was opened in 1985.

This laboratory was one of the prominent centers of its kind in Turkey. At that time it was equipped with five Zeiss research microscopes and many microsurgical instruments. The first practical course in microsurgery was initiated by November 18, 1985. More equipment was added later. The equipment of the experimental lab is now well suited for both educational and research activities. The lab is equipped with 5 experimental Zeiss OpMi-1 and
OpMi-6 surgical microscopes and other instruments required for microsurgical interventions (Figure 1) This way one can perform microsurgical interventions as one or as a part of an operative team. The video systems attached to some of the microscopes allow viewing and videotaping of the microsurgical exercises, and evaluation of the accuracy of the technique; thus, facilitating the learning process. Computers and multimedia devices are also available together with educational materials providing new and better ways to learn and understand the microsurgical techniques. A classroom was also designed for the education of the students on the history and techniques of microsurgery, as well as for the instruments and animals that are used in the courses and researches (Figure 2). The course programs and documents were provided by Dr. Ergin Yuce M.C. He was a biologist and made great contributions to the founding and direction of the laboratory. He passed away seven years ago in 2003 due to lymphoma.

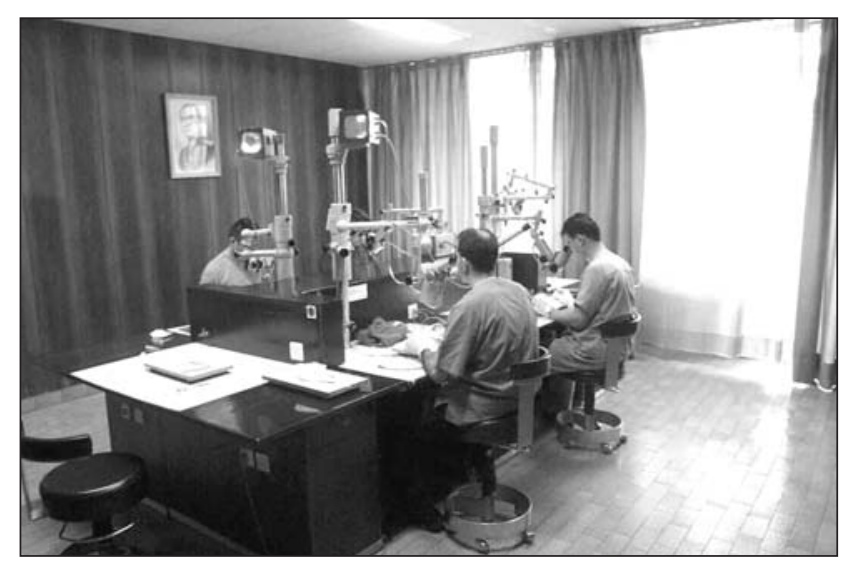

Figure 1: The microsurgical laboratory during a course.

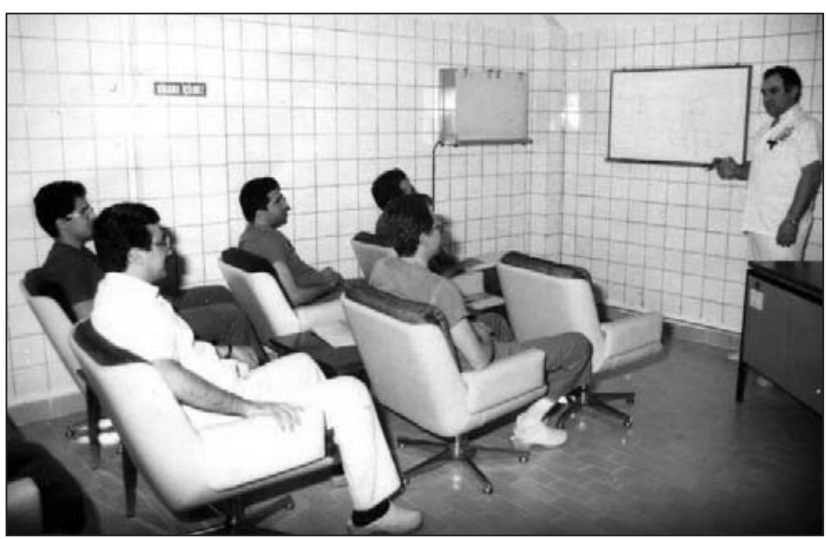

Figure 2: The classroom of the laboratory for the seminars on microsurgery. 
The purpose of this microsurgery teaching laboratory is to provide the basic foundations of the principles and skills that make up good microsurgical techniques for general surgeons, plastic surgeons, cardiovascular surgeons, neurosurgeons, urologists, gynecologists, otolaryngologists, ophthalmologists and pediatric surgeons. The goal is not simply to teach the mechanics of placing a microsuture, but to teach an organized, step-by-step approach to success in microsurgery. In collaboration with the other clinics, the microsurgical techniques were implemented also in neurosurgery, maxillo-facial surgery, otorhinolaryngology, urological, pediatric surgery and orthopedics.

A total of 288 courses were performed until today. Not only military surgeons but also many surgeons from the civilian universities and education hospitals were trained in this laboratory. A total of 1082 physicians were educated over a 25year period. A lot of surgeons from the neighbouring countries also took this course. The experimental research focused on the study of vascular anastomoses, the microsurgery of the peripheral nerve, the effects of cerebral ischaemia, and tissue revascularization. The anatomical researches focused on the cranial nerves, orbit, ventricles and other cerebral regions.

The course involves 45 hours of instruction starting Monday morning and ending Friday afternoon. In the first day, the history of microsurgery, the effects of microsurgery on surgical interventions, the knowledge on operation microscope and microsurgical instruments, and microsuture techniques under magnification were given to the students. Microdissection on the rats and end-to-end anastomosis of the internal carotid arteries of rats are the topics of the second day. On the third and fourth days, the students perform practical applications of microtechniques. End-toside anastomosis and experimental aneurysm models in common carotid artery of the rats are reserved for the last day of the course (Figure $3 \mathrm{~A}, \mathrm{~B}, \mathrm{C}, \mathrm{D})$. All students perform microvascular anastomoses on the last day of the course. The course uses video demonstrations followed by practical, hands-on exercises with the instructor. The course focuses on basic microsurgical skills including arterial anastomoses, end-to-end, interpositional grafting, and end-to-side anastomoses. The course was designed to teach surgeons with no microsurgical experience. However, the curriculum is equally valuable for individuals who have had some microsurgical training but want to make a new beginning in order to strengthen and upgrade their skills.

Due to the excellent collaboration between the microsurgical laboratory and Research-Development Center at GMMA, both short term and long term experiments on animals are possible. The ResearchDevelopment Center provides the animals required during the courses which were organized in the laboratory.

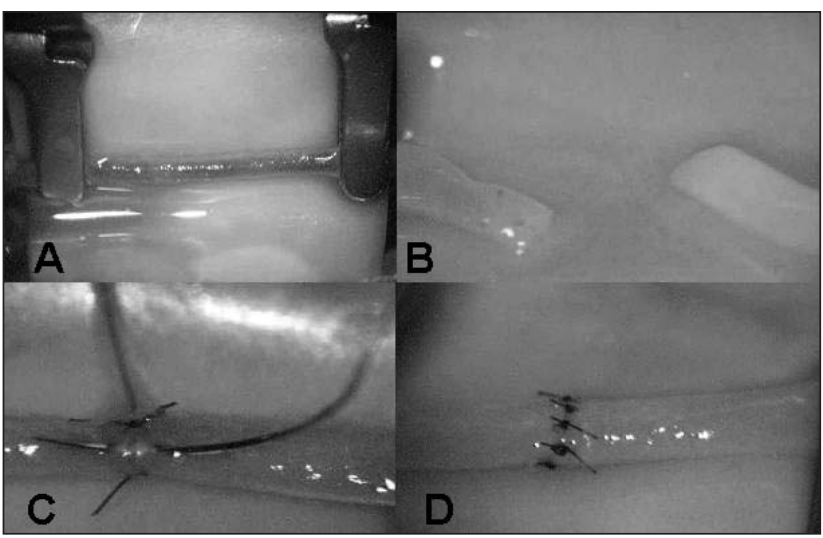

Figure 3: (A) Clipping of the common carotid artery (CCA) in the neck of a rat is the first step of the course. (B) The CCA was cut from the midpoint. (C) The tips of the CCA were anastomosed by 10.0 silk sutures under magnification. (D) The artery was patent after the anastomosis.

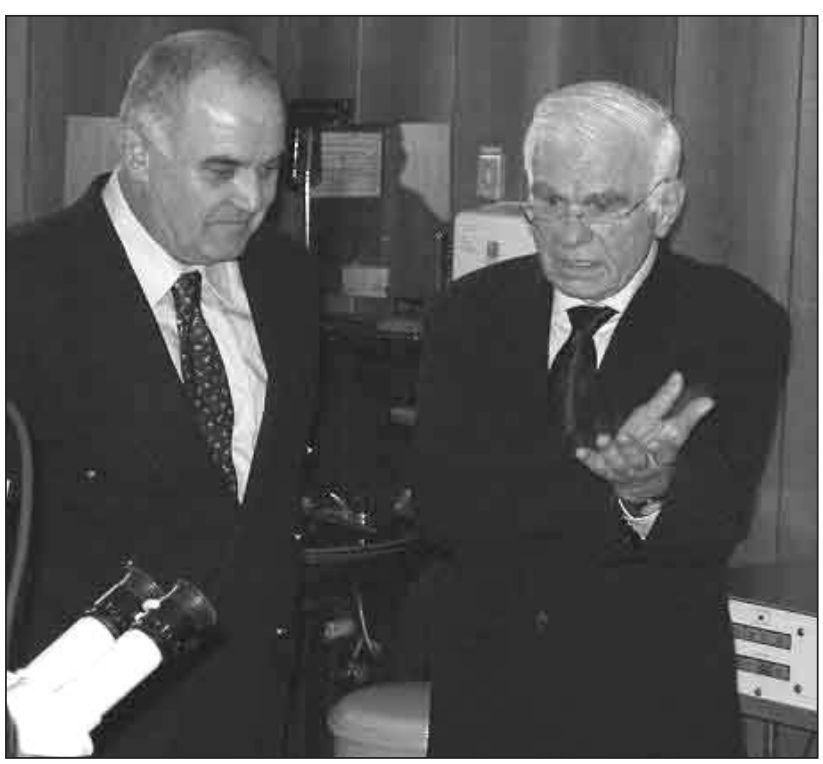

Figure 4: The visit of Prof. Yasargil in 2004. He discussed the laboratory and the courses with Prof. Timurkaynak. 
More than 1000 surgeons were educated in 288 courses until today. Table I demonstrates the number of military and civilian surgeons who learned microsurgical techniques in this laboratory. Table II summarizes the distribution of the surgeons according to their sub-specialties. The general surgeons constitute the majority of the students and a small number of cardiovascular surgeons took this course over a period of 25 years.

Prof. Yaşargil visited this laboratory two-times in 1992 and 2004 and he was fascinated by the design of the training room and the instruments that are used in the laboratory (Figure 4)

Table I: The Numbers of Courses and Students for Every 5 Years.

\begin{tabular}{|l|c|c|c|c|}
\hline Year & Number of Courses & Military Surgeon & Civilian Surgeon & Total \\
\hline $1985-1989$ & 55 & 215 & 9 & 224 \\
\hline $1990-1994$ & 61 & 191 & 37 & 228 \\
\hline $1995-1999$ & 73 & 216 & 56 & 272 \\
\hline $2000-2004$ & 62 & 182 & 40 & 222 \\
\hline $2005-2009$ & 37 & 88 & 48 & 136 \\
\hline TOTAL & 288 & $892(82.5 \%)$ & $190(17.5 \%)$ & 1082 \\
\hline
\end{tabular}

Table II: The Number and Percentage of the Students According to Their Fields.

\begin{tabular}{|l|c|c|}
\hline Speciality & $\begin{array}{c}\text { Number of } \\
\text { students }\end{array}$ & $\begin{array}{c}\text { Percent } \\
\mathbf{( \% )}\end{array}$ \\
\hline General Surgeon & 269 & 24.9 \\
\hline Orthopedics & 172 & 15.9 \\
\hline Neurosurgeon & 107 & 9.9 \\
\hline Ophthalmologist & 101 & 9.3 \\
\hline Otolaryngologist & 99 & 9.1 \\
\hline Gynecologist & 97 & 9 \\
\hline Urologist & 85 & 7.8 \\
\hline Plastic Surgeon & 76 & 7 \\
\hline Chest Surgeon & 23 & 2.1 \\
\hline Pediatric Surgeon & 23 & 2.1 \\
\hline $\begin{array}{l}\text { Cardiovascular } \\
\text { Surgeon }\end{array}$ & 19 & 1.8 \\
\hline Dentist & 10 & 1 \\
\hline Emergency Medicine & 1 & 0.1 \\
\hline TOTAL & 1082 & 100 \\
\hline
\end{tabular}

\section{CONCLUSION}

Today, the laboratory combines research projects with educational programs. Some of the surgeons that have gained their microsurgical skills from the very beginning are now involved in coordinating research projects and take part in organizing the courses. For the best development of the courses, students who are interested in this medical field bring their own contribution as well.

\section{REFERENCES}

1. Donaghy RMP: History of micro-neurosurgery, in Wilkins RH, Rengachary SS. (eds): Neurosurgery, 2nd ed. New York: McGraw-Hill, 1996: 37-42

2. Link TE, Bisson E, Horgan MA, Tranmer BI: Raymond M. P. Donaghy: A pioneer in microneurosurgery. Historical vignette. J Neurosurg. 2009 Sep 11. [Epub ahead of print]

3. Timurkaynak E, Izci Y, Acar F: 116 years (1889-2005) of neurosurgical practice and education at Gulhane Military Medical Academy. Neurosurgery. 58:577-581, 2006 